\title{
Characterization and Mössbauer spectroscopy of steel slag generated in the ladle furnance in SIDERPERU steel plant
}

\author{
A. G. Bustamante Dominguez ${ }^{1}$ - M. I. Valerio-Cuadros ${ }^{1,2}$. \\ L. E. Borja-Castro ${ }^{1} \cdot$ R. A. Valencia-Bedregal ${ }^{1}$ - J. Flores Santibañez ${ }^{1}$. \\ S. M. Espinoza Suarez ${ }^{1} \cdot$ H. Cabrera-Tinoco ${ }^{1,3} \cdot$ N.O Moreno $^{4} \cdot$ C. H. W. Barnes ${ }^{5}$. \\ L. De Los Santos Valladares ${ }^{1,5,6}$ (D)
}

Accepted: 1 February 2022 / Published online: 9 February 2022

(c) The Author(s) 2022

\begin{abstract}
The steel industry produces large amounts of slag coming from different stages during the steelmaking process every year. Currently, there are numerous attempts to recycle it or to use it in some other industry sectors and to preserve the environment. The characteristics of the slag depends on the steelmaking process and it is crucial to have it before any attempt of recycling. In this work, slag sample produced in the ladle furnace from SIDERPERU steel plant were collected and analyzed by using energy dispersion X-ray (EDX), X-ray diffraction (XRD), X-ray fluorescence spectroscopy (XRF), SQUID magnetometer and Mössbauer spectroscopy. The chemical analysis obtained by EDX and $\mathrm{XRF}$ indicate that the main elemental composition of the material is $\mathrm{Fe}, \mathrm{Ca}, \mathrm{Si}$ and $\mathrm{Cr}$. XRD identifies that these elements are in the phases: $\mathrm{FeO}, \mathrm{Fe}_{3} \mathrm{O}_{4}, \alpha-\mathrm{Fe}_{2} \mathrm{O}_{3}, \mathrm{Ca}_{2} \mathrm{SiO}_{4}$, and $\mathrm{Ca}_{2,32} \mathrm{Mn}_{0,68} \mathrm{SiO}_{7}$. Magnetometry measurements suggest the Verwey transition for magnetite and the Morin transition for hematite are screened by the presence of superparamagnetic phases. The Mössbauer spectrum shows two doublets related to $\mathrm{Fe}^{2+}$ and $\mathrm{Fe}^{3+}$ ions with hyperfine parameters belonging to that of non-stoichiometric wustite. Also, the presence of hyperfine fields characteristic of the $\mathrm{Fe}_{3} \mathrm{O}_{4}$ and $\mathrm{Fe}_{2} \mathrm{O}_{3}$ phase identified at room temperature verifies the magnetometry analysis. The analysis of the sample used in this work reveals details connected with the steel fabrication processes and are helpful for posterior recycling attempts.
\end{abstract}

Keywords Ladle Furnace $\cdot$ Steel slag $\cdot$ Steelmaking process $\cdot$ Mössbauer Spectroscopy · Iron oxides

This article is part of the Topical Collection on Proceedings of the International Conference on the Applications of the Mössbauer Effect (ICAME 2021), 5-10 September 2021, Brasov, Romania Edited by Victor Kuncser

A. G. Bustamante Dominguez abustamanted@unmsm.edu.pe

L. De Los Santos Valladares 1d301@cam.ac.uk

Extended author information available on the last page of the article 


\section{Introduction}

The metallurgical slag is a by-product material generated during the steelmaking process. Large amounts of slags are produced in the steel industry and increase every year generating pollution and affecting the environment [1]. Some attempts in reusing steel slags include raw material for road construction, pavements, bricks and concrete [2-4]. The partial replacement of cement by steel slags makes a significant contribution to the steel industry and helps to reduce $\mathrm{CO}_{2}$ emissions [2]. Thus, finding an appropriate use of steel slags is very important for both, to reduce the potential impact on the environment and to maintain the sustainability of natural resources $[5,6]$.

Steel slags are formed during the melting of iron ore or iron scrap and subsequently discharged as waste [7]. Depending on the type of steel, the slags can be classified as carbon steel slag or stainless-steel slag [8,9]. Slags can also be classified depending on the step during the steelmaking process they were generated i.e., basic oxygen furnace (BOF) slag, electrical arc furnace (EAF) slag, ladle furnace (LF) slag and continuous casting residue. Many research have been focused on the characterization of steel slags produced in an EAF. For example, Yildirim and Prezzi, reported that the main contents in the slags from EAFs are typically $\mathrm{FeO}, \mathrm{CaO}$ and $\mathrm{SiO}_{2}$ and similar works that report the common compounds [7, 8]. However, the characterization and recycling of LF slags (LFS) are less widespread. Nevertheless, there are some attempts to recycle LFS as Portland cement, soil stabilization and asphalt mixes due to high calcium content [10-13]. Since the composition of the LFS varies according to the scrap used, it is necessary to know the characteristics and chemical and physical properties of these slags before recycling and to decide the best strategy to recover the metals.

In this work, we present the characterization of the slags produced during the second step process of steel in a ladle furnace from SIDERPERU in order to facilitate the recycling of the steel in Peru.

\section{Experimental}

The samples were collected from SIDERPERU steel plant, Chimbote, Peru. The steelmaking process in this steel plant consists of three different stages: A melting process in an Electric Arc Furnace (EAF), the forming of chemical equilibrium between $\mathrm{Fe}, \mathrm{Ca}$ and other components in a Ladle Furnace (LF), and the solidification through continuous casting. During the second stage, some melted steel remains stuck at the internal walls of the LF, which are discarded after the melting steel reaches its chemical equilibrium and dried to room temperature. Tons of this slag are produced every week and they are crushed for recycling. Several kilograms of this material were collected during this work and named as 'remanent' sample, as listed in Table 1. Whereas, before recycling, magnetic drums are

Table 1 Difference between slag samples collected after treatment in the ladle furnace at SIDERPERU

\begin{tabular}{lll}
\hline Sample & Source & Factory treatment \\
\hline Remanent & $\begin{array}{l}\text { Melted steel stuck in the internal walls of the } \\
\text { ladle furnace } \\
\text { Crushed remanent sample }\end{array}$ & Dried in normal conditions \\
Demetallized & Crugnetically separated \\
\hline
\end{tabular}


approached to the crushed material with the aim to extract the remaining Fe. The left-over material from this process is then thrown away by SIDERPERU and collected in this work and called as 'demetallized' slag (see Table 1).

The collected samples were powdered and sieved down to $72 \mu \mathrm{m}$ for better performance analysis in order to increase the accuracy of measurements. The obtained powders were stored in two Eppendorf (each containing one sample), from which they supplied for each characterization technique. The morphology of the samples was inspected through a scanning electron microscope (SEM, Philipps XL30) with a resolution of $10 \mathrm{~nm}$ at $30 \mathrm{kV}$, voltage range: $0.5 \mathrm{~V}$ to $30 \mathrm{kV}$ and magnification of $300,000 \times$ adapted with an energy dispersive X-ray (EDX) spectrometer OXFORD Xplorer. An XRF-720 Shimadzu equipment was used to register the elemental composition of the sample, which counts with an advantage algorithm that allows analyzing a variety of types of matrices. The X-ray diffraction (XRD) measurements were performed in a Rigaku brand diffractometer using a cobalt target $\left(\lambda_{\mathrm{K} \alpha}=1.79026 \AA\right)$ with $10^{\circ} \leq 2 \theta \leq 90^{\circ}$, step width $0.02^{\circ}$ and speed of $4 \mathrm{~s} / \mathrm{step}$. The Co-target was used for XRD since, in contrast to other targets, it increases the diffraction signal of iron-containing minerals. The magnetic measurements were carried out using a DC-MPMS-SQUID magnetometer (Quantum Design Inc.) in zero field cooling (ZFC) and field cooling (FC) modes. The magnetization response as a function of temperature was collected from 5 to $400 \mathrm{~K}$ and applying external magnetic fields of $500 \mathrm{Oe}$ and $10 \mathrm{kOe}$. The applied field response of the magnetization was also measured in the range $\pm 10 \mathrm{kOe}$ at 5, 300 and $400 \mathrm{~K}$. The Mössbauer spectroscopy of the sieved samples were performed at room temperature (RT) using a Mössbauer spectrometer in transmission geometry with a radioactive source of ${ }^{57} \mathrm{Co}(\mathrm{Rh})$ with $50 \mathrm{mCi}$ current activity with a constant acceleration function. The data were registered in a multichannel analyzer with counting data stored in 1024 channels platform. For the calibration measurement, a thin $\alpha$-Fe foil was used. The fitting process was carried out considering Lorentzian profiles using the WinNormos software.

\section{Results and Discussions}

Figure 1a shows a dried piece of the remanent slag stucked in the ladle furnace from SIDERPERU steel plant and in Fig. 1b a piece of the demetallized slag after crushing the remanent slag is also shown. Theses slags are hard sponge stones, with irregular shape and have many pores probably caused by release of gases during melting and quenching. Fig. 1c shows a SEM micrograph of remanent sample revealing a rough surface with many pores suggesting that it boiled at high temperatures during many hours. The SEM micrograph for the demetallized slag sample shown in Fig. 1d presents a quite spheroidal grain with no rough surface and diameter size around to $100 \mu \mathrm{m}$ revealing also the presence of nanoparticles. According to the SEM images, $\mathrm{Ca}$ and $\mathrm{Fe}$ are the predominate elements spread over the whole samples as indicated by the mapping colors. Figs. 1e,f show the respective EDX sum-spectra. Whereas, the respective XRF spectra are shown in Figs. 1g,h. The element quantification provided by both techniques are listed in Table 2. According to it, $\mathrm{Fe}, \mathrm{Ca}$ and $\mathrm{Si}$ are the main component elements. However, the EDX analysis also detects $\mathrm{Mn}, \mathrm{Cr}$ and $\mathrm{Zn}$ as secondary elements. Moreover, XRF also detects $\mathrm{Cr}, \mathrm{Ti}, \mathrm{K}, \mathrm{Sr}, \mathrm{Nb}, \mathrm{Zr}$, $\mathrm{Zn}$ for both samples. This difference in secondary elemental detection is due the accuracy 

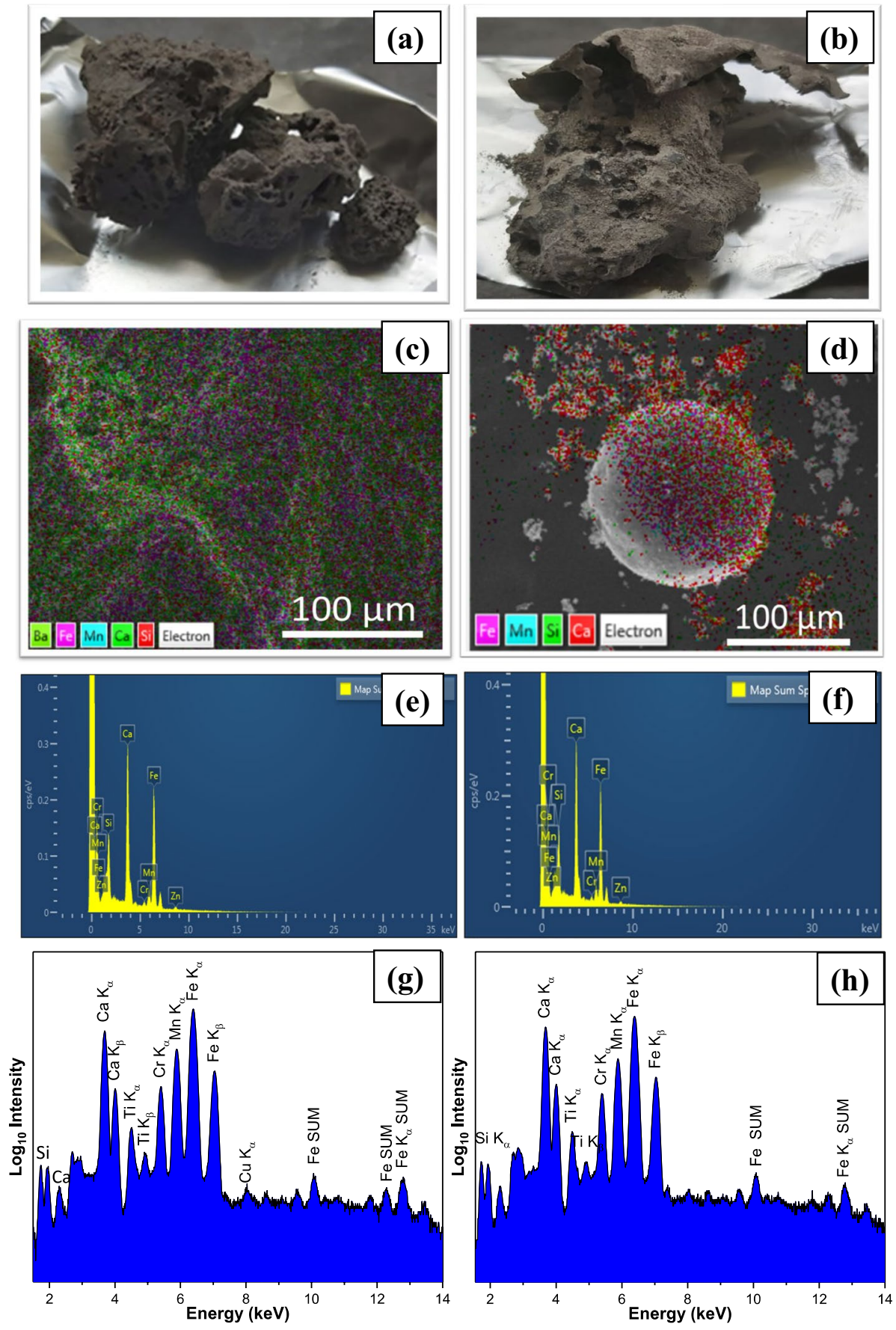

Fig. 1 a and b Ladle furnace slag remanent and demetallized, $\mathbf{c}$ and $\mathbf{d}$ SEM micrography and color mapping for remanent and demetallized slag, $\mathbf{e}$ and $\mathbf{f}$ EDX sum spectrum and $\mathbf{g}$ and $\mathbf{h} \mathbf{X}$ ray fluorescence of remanent and demetallized ladle furnace slag. 
Table 2 Elemental Composition of remanent and demetallized slag generated in the ladle furnace from SIDERPERU steel plant

\begin{tabular}{|c|c|c|c|c|c|c|c|c|c|c|}
\hline Sample & EDX & & & & & & & & & \\
\hline \multirow[t]{7}{*}{ Remanent } & Element & $\mathrm{Fe}$ & $\mathrm{Ca}$ & $\mathrm{Si}$ & $\mathrm{Zn}$ & $\mathrm{Cr}$ & & & & \\
\hline & wt (\%) & 46.98 & 30.22 & 12.2 & 2.2 & 1.49 & & & & \\
\hline & \multicolumn{10}{|c|}{ XRF } \\
\hline & Element & $\mathrm{Fe}$ & $\mathrm{Ca}$ & $\mathrm{Si}$ & $\mathrm{Cr}$ & $\mathrm{Ti}$ & $\mathrm{K}$ & $\mathrm{Sr}$ & $\mathrm{Nb}$ & $\mathrm{Zr}$ \\
\hline & Mass \% & 47.2 & 29.3 & 17.6 & 3.49 & 1.217 & 0.359 & 0.311 & 0.122 & 0.064 \\
\hline & Element & $\mathrm{Zn}$ & $\mathrm{Rb}$ & & & & & & & \\
\hline & Mass \% & 0.051 & 0.017 & & & & & & & \\
\hline \multirow[t]{8}{*}{ Demetallized } & \multicolumn{10}{|c|}{ EDX } \\
\hline & Element & $\mathrm{Fe}$ & $\mathrm{Ca}$ & $\mathrm{Si}$ & $\mathrm{Mn}$ & & & & & \\
\hline & wt $(\%)$ & 26.8 & 53.45 & 9.12 & 10.13 & & & & & \\
\hline & \multicolumn{10}{|c|}{ XRF } \\
\hline & Element & $\mathrm{Fe}$ & $\mathrm{Ca}$ & $\mathrm{Si}$ & $\mathrm{Mn}$ & $\mathrm{Cr}$ & $\mathrm{Ti}$ & $\mathrm{Sr}$ & $\mathrm{Nb}$ & $\mathrm{Zr}$ \\
\hline & Mass \% & 35.54 & 32.89 & 9.62 & 8.047 & 2.616 & 0.359 & 0.46 & 0.043 & 0.076 \\
\hline & Element & $\mathrm{Cu}$ & & & & & & & & \\
\hline & Mass \% & 0.065 & & & & & & & & \\
\hline
\end{tabular}
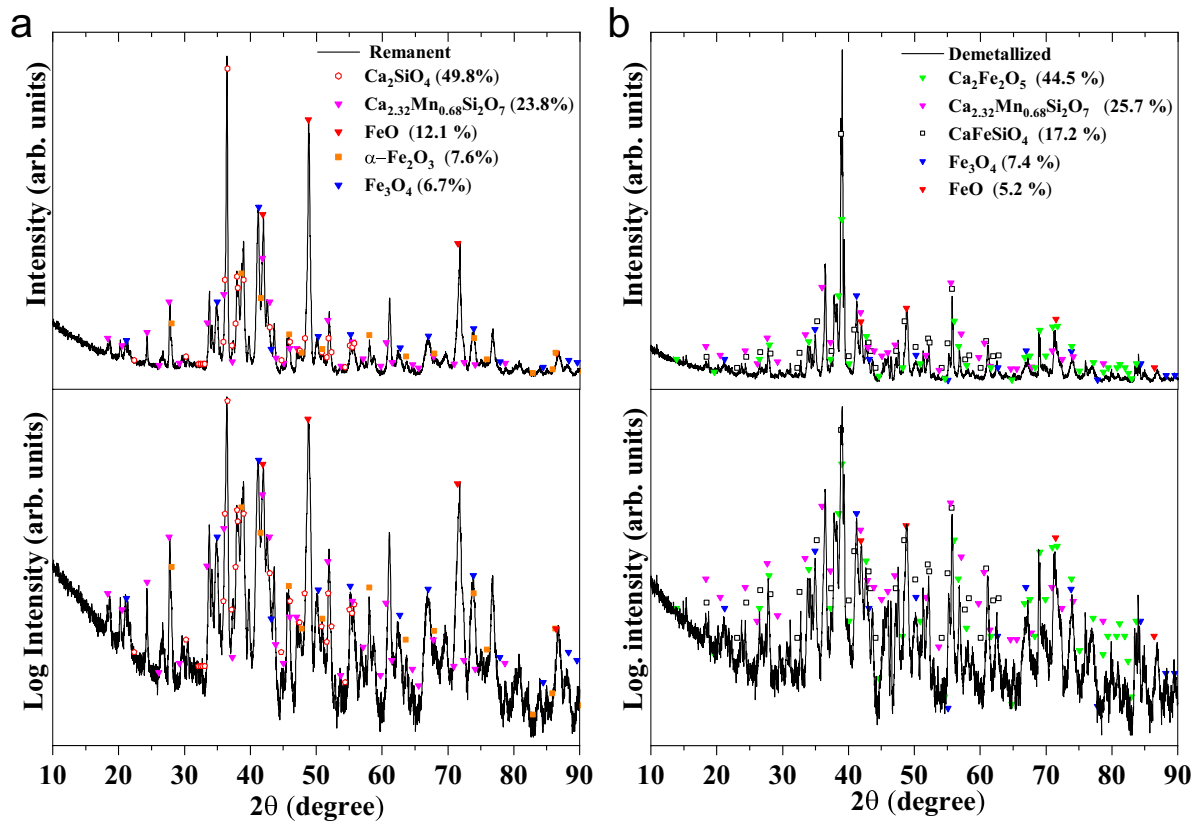

Fig. 2 X-ray diffractogram of metallurgical slag produced in a ladle furnace during steelmaking process in SIDERPERU plants. a) remanent slag, b) demetallized slag 

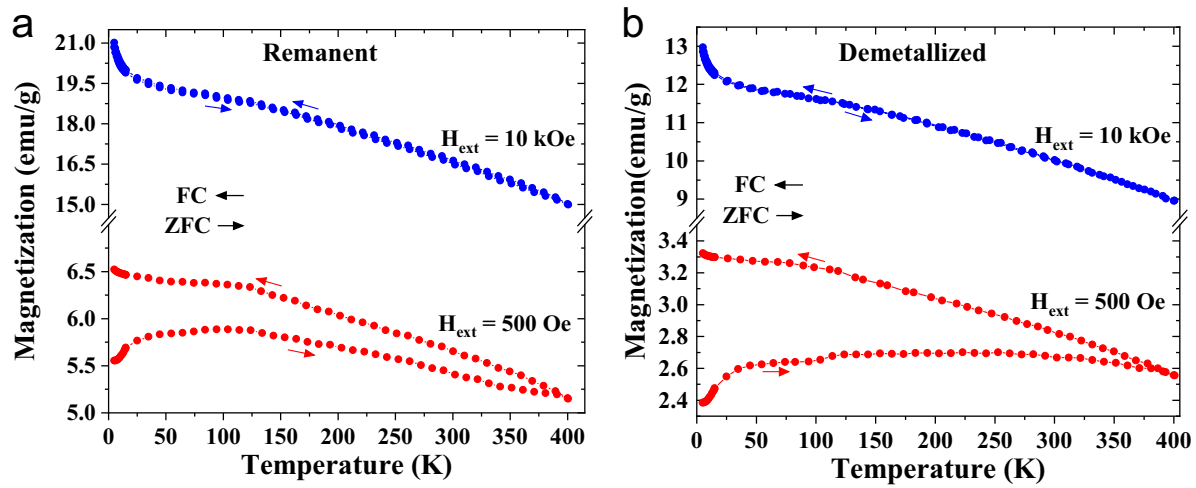

Fig. 3 Magnetization response as a function of the temperature for the remanent (a) and demetallized (b) slags collected from SIDERPERU steel plant

of both techniques. Compared to EDX, XRF has a larger penetration depth and is able to detect more elements.

Figure 2 shows the X-ray diffractograms of the slags. The abundance of the different phases identified by XRD are given in the legends in the plots. According to Fig. 2(a), the main crystalline phases identified by the XRD for the remanent slag are larnite $\left(\mathrm{Ca}_{2} \mathrm{SiO}_{4}\right.$, PDF card N0. 00-029-0369), ankerite $\left(\mathrm{Ca}_{2.32} \mathrm{Mn}_{0.68} \mathrm{Si}_{2} \mathrm{O}_{7}\right.$ PDF card N0. 00-040-0054), wustite (FeO, PDF card N0. 01-073-2143), hematite ( $\alpha-\mathrm{Fe}_{2} \mathrm{O}_{3}$, PDF card N0. 00-086-2368) and magnetite $\left(\mathrm{Fe}_{3} \mathrm{O}_{4}\right.$, PDF card N0. 01-086-1355). Larnite could be formed by the reaction of $\mathrm{CaO}$ and $\mathrm{SiO}_{2}$ due to reactants added during the melting process of the initial scraps in the electrical furnace [14], whereas ankerite $\mathrm{Ca}_{2.32} \mathrm{Mn}_{0.68} \mathrm{Si}_{2} \mathrm{O}_{7}$ is a non-stoichiometric mineral that can occur due to reaction of $\mathrm{MnO}, \mathrm{CaO}$ and $\mathrm{SiO}_{2}$. The X-ray diffractogram for the demetallized slag (see Fig. 2(b)) reveals a mineralogical phase of the brownmillerite subgroup known as srebrodolskite $\left(\mathrm{Ca}_{2} \mathrm{Fe}_{2} \mathrm{O}_{5}\right.$, PDF card N0. 00-047-1744), ankerite $\left(\mathrm{Ca}_{2.32} \mathrm{Mn}_{0.68} \mathrm{Si}_{2} \mathrm{O}_{7}\right.$, PDF card N0. 00-040-0054), kirschteinite $\left(\mathrm{CaFeSiO}_{4}\right.$, PDF card N0. 00-011-0477), magnetite and wustite. The XRD for both samples are also shown in logarithmical scale in order to observe the smaller peaks. Srebrodolskite should occurr at temperatures above $750{ }^{\circ} \mathrm{C}$ by the reaction of the $\mathrm{Fe}$ components in the slags with $\mathrm{CaCO}_{3}$, which is used for lowering the melting point of the steel. $\alpha-\mathrm{Fe}_{2} \mathrm{O}_{3}$ was formed by the oxidation of wustite with the oxygen gas injected during melting of steel scrap in the initial electrical arc furnace. Moreover, kirschteinite could be formed by reaction of $\mathrm{CaO}, \mathrm{FeO}$ and $\mathrm{SiO}_{2}$ at $1460{ }^{\circ} \mathrm{C}$ during the reduction process of scrap melted in the ladle furnace. Furthermore, the non-stoichiometric ankerite might have formed during the reaction of $\mathrm{MnO}$, $\mathrm{CaO}$ and $\mathrm{SiO}_{2}$. These mineralogical phases are commonly found in steel slag reported in literature $[7,8,15,16]$. The results obtained here are in agreement with the EDX and XRF analysis above, which registered $\mathrm{Fe}$ and $\mathrm{Ca}$ as the major components.

Figures 3(a) and (b) show the magnetization response as a function of the temperature $(\mathrm{M}(\mathrm{T}))$ curves taken in ZFC and FC modes under $500 \mathrm{Oe}$ and $10 \mathrm{kOe}$ external field of the remanent and demetallized samples, respectively. Note that at any temperature and external field, the magnetization values for the remanent sample are higher than those for the demetallized one. This is because the remanent sample contains higher amount of iron than the demetallized sample as discussed in the chemical composition analysis above. Besides, it is not clear the cause of the relative high values of the magnetization in both cases. To name, 


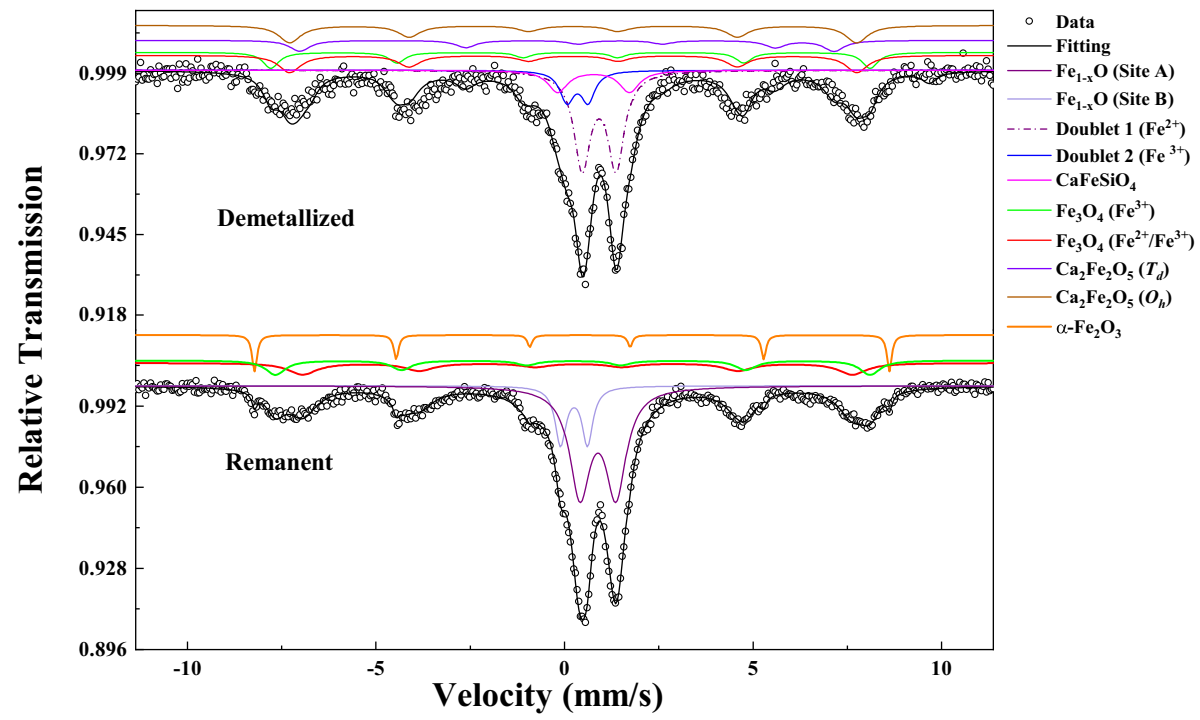

Fig. 4 Mössbauer spectra at RT of a slag produced in a ladle furnace during steelmaking process in SIDERPERU plant

the magnetization values provided by the paramagnetic phases, such as wustite and iron silicates, are lower than $1 \mathrm{emu} / \mathrm{g}$ [17-19] in contrast to Fig. 3(a) and (b). Moreover, it is uncertain that the high magnetization values be caused by the ferrimagnetic magnetite nor antiferromagnetic hematite present in the samples, as detected by the XRD analysis above. Furthermore, the Verwey [20] and Morin [21] transitions for magnetite and hematite are not detected in the $\mathrm{M}(\mathrm{T})$ curves. Instead, an apparent blocking state is noted at low temperatures in the ZFC curves taken under 500 Oe applied field in both samples. Thus, the relative high values of the magnetization and this blocking state in the $\mathrm{M}(\mathrm{T})$ curves suggest that both samples contain certain amount of magnetic nanoparticles. Nanoparticles are not indicated by XRD due to the overlapping of multiple mineralogical phases, whose superparamagnetic signals in Fig. 3 might screen the Verwey and Morin signals of the magnetite and hematite, respectively. In addition, the irreversibility over the whole temperature range of the ZFC and FC curves obtained under 500 Oe for both samples, become reversible under a higher applied field, such as $10 \mathrm{kOe}$. In this way, increasing the applied field tends to align all magnetic domains present in the sample to the direction of this external field resulting in gaining of magnetization. As a complementary information, the magnetization as a function of the external field is given in the Supplemental Material S1.

The Mössbauer spectra for both samples at room temperature are shown in Fig. 4 and the obtained hyperfine parameters are listed in Table 3. The spectra for both samples are quite similar as shown in Fig. 4. The fitting process was performed using sextets and doublets subspectra. The two-broad lines absorption in the central parts of the spectra might come from the iron silicates and/or calcium iron compounds detected by the XRD analysis above. Moreover, according to the literature [22, 23], the electronic exchange between $\mathrm{Fe}^{2+}$ in octahedral site and $\mathrm{Fe}^{3+}$ in tetrahedral site and the electronic exchange of tetrahedral $\mathrm{Fe}^{3+}$ and $\mathrm{Fe}^{2+} / \mathrm{Fe}^{3+}$ octahedral sites produce two paramagnetic doublets that can be related to non-stoichiometric wustite. For the remanent slag sample, the hyperfine parameters associated to wustite are $\mathrm{IS}=0.99 \mathrm{~mm} / \mathrm{s}$ 
Table 3 Hyperfine Mössbauer parameters of the slags produced in the ladle furnace from SIDERPERU steel plant during steelmaking process

\begin{tabular}{|c|c|c|c|c|c|c|}
\hline Sample & Site & IS $(\mathrm{mm} / \mathrm{s})$ & $\mathrm{QS}(\mathrm{mm} / \mathrm{s})$ & $\operatorname{Bhf}(\mathrm{T})$ & $\mathrm{W}(\mathrm{mm} / \mathrm{s})$ & Area $(\%)$ \\
\hline \multirow[t]{5}{*}{ Remanent } & $\mathrm{Fe}_{1-\mathrm{x}} \mathrm{O}\left(\mathrm{Fe}^{2+}\right)$ & $0.99(2)$ & $1.01(1)$ & - & $0.64(3)$ & 53.3 \\
\hline & $\mathrm{Fe}_{1-\mathrm{x}} \mathrm{O}\left(\mathrm{Fe}^{3+}\right)$ & $0.36(2)$ & $0.71(1)$ & - & $0.34(3)$ & 8.0 \\
\hline & Magnetite $\left(\mathrm{Fe}^{2+} / \mathrm{Fe}^{3+}\right)$ & $0.47(3)$ & $-0.02(2)$ & $45.2(1)$ & $0.85(5)$ & 22.9 \\
\hline & $\begin{array}{l}\text { Magnetite } \\
\left(\mathrm{Fe}^{3+}\right)\end{array}$ & $0.33(2)$ & -.0 .02 & $48.8(4)$ & $0.6(2)$ & 13.9 \\
\hline & Hematite $\left(\mathrm{Fe}^{3+}\right)$ & $0.41(2)$ & $-0.21(2)$ & $52.2(0)$ & $0.14(3)$ & 1.9 \\
\hline \multirow[t]{7}{*}{ Demetallized } & Doublet $1\left(\mathrm{Fe}^{2+}\right)$ & $0.90(1)$ & $1.00(2)$ & - & $0.50(3)$ & 33.5 \\
\hline & Doublet $2\left(\mathrm{Fe}^{3+}\right)$ & $0.46(1)$ & $0.52(1)$ & - & $0.42(3)$ & 7.3 \\
\hline & $\mathrm{CaFeSiO}_{4}\left(\mathrm{Fe}^{2+}\right)$ & $0.87(1)$ & $1.89(1)$ & - & $0.63(1)$ & 11.1 \\
\hline & Magnetite $\left(\mathrm{Fe}^{3+}\right)$ & $0.26(5)$ & - & $49.2(5)$ & $0.51(1)$ & 10.6 \\
\hline & $\begin{array}{l}\text { Magnetite } \\
\left(\mathrm{Fe}^{2+} / \mathrm{Fe}^{3+}\right)\end{array}$ & $0.34(1)$ & - & $46.6(1)$ & $0.70(2)$ & 21.5 \\
\hline & $\mathrm{Ca}_{2} \mathrm{Fe}_{2} \mathrm{O}_{5}\left(\mathrm{~T}_{\mathrm{d}}\right)$ & $0.70(2)$ & $-1.4(1)$ & $43.9(2)$ & $0.63(1)$ & 11.5 \\
\hline & $\mathrm{Ca}_{2} \mathrm{Fe}_{2} \mathrm{O}_{5}\left(\mathrm{O}_{\mathrm{h}}\right)$ & $0.77(3)$ & $1.36(1)$ & $50.85(2)$ & $0.55(2)$ & 4.5 \\
\hline
\end{tabular}

and $\mathrm{QS}=1.01 \mathrm{~mm} / \mathrm{s}$, and $\mathrm{IS}=0.36 \mathrm{~mm} / \mathrm{s}$ and $\mathrm{QS}=0.71 \mathrm{~mm} / \mathrm{s}$. Similarly, the hyperfine parameters $\mathrm{IS}=0.90 \mathrm{~mm} / \mathrm{s}$ and $\mathrm{QS}=1.0 \mathrm{~mm} / \mathrm{s}$ and a tiny doublet with $\mathrm{IS}=0.38 \mathrm{~mm} / \mathrm{s}$ and $\mathrm{QS}=0.52 \mathrm{~mm} / \mathrm{s}$ in the oxidation state of $\mathrm{Fe}^{3+}$ were found for the demetallized slag. Note that, in contrast to the XRD of the demetallized sample above in which wustite represents the smaller component, the corresponding MS presents this oxide having the highest relative absorption area (\%). This might be caused by the presence of superparamagnetic Fe-oxides (such as wustite nanoparticles), as suggested by the respective SEM micrograph (Fig. 1(d)) and the magnetometry analysis (Fig. 3(b)) above. In this way, the purple doublet marked with dashed dots in Fig. 4 (Doublet $\left.1\left(\mathrm{Fe}^{2+}\right)\right)$ is assumed to correspond to superparamagnetic wustite. Two sextets with hyperfine magnetic fields $\mathrm{B}_{\mathrm{hf}}=45.2 \mathrm{~T}$ and $\mathrm{B}_{\mathrm{hf}}=48.8 \mathrm{~T}$, typical for magnetite in octahedral $\left(\mathrm{Fe}^{3+} / \mathrm{Fe}^{2+}\right)$ and tetrahedral $\mathrm{Fe}^{3+}$ sites [24-26], were found in the remanent slag. Additionally, another two sextets with hyperfine fields $\mathrm{B}_{\mathrm{hf}}=49.2 \mathrm{~T}$ and $46.6 \mathrm{~T}$ that also could be associated to magnetite were obtained in demetallized slag which agrees to XRD results above. The rate areas between the octahedral and tetrahedral sites in the magnetite for both samples is around 1.8 (pure magnetite) [27], this suggests a nonstoichiometric magnetite due to partial substitutions by the other chemical elements registered by EDX and XRF above. A small sextet related to hematite hyperfine parameters $[28,29]$ is also observed for the remanent sample. The other two remaining sextets in demetallized slag belong to srebrodolskite $\left(\mathrm{Ca}_{2} \mathrm{Fe}_{2} \mathrm{O}_{5}\right)$, which was also detected by XRD, in octahedral and tetrahedral sites with $\mathrm{Fe}^{2+}$ and $\mathrm{Fe}^{3+}$ oxidation states with $\mathrm{B}_{\mathrm{hf}}=43.9 \mathrm{~T}$ and $\mathrm{B}_{\mathrm{hf}}=50.85 \mathrm{~T}$ [30], respectively. $\mathrm{Ca}_{2} \mathrm{Fe}_{2} \mathrm{SiO}_{4}$ detected by XRD in the demetallized slag was associated with a doublet in $\mathrm{Fe}^{2+}$ oxidation state with hyperfine parameters of $\mathrm{IS}=0.87 \mathrm{~mm} / \mathrm{s}$ and $\mathrm{QS}=1.89 \mathrm{~mm} / \mathrm{s}$ [31].

The information provided in the present work would be very useful for posterior attempts to recycle these types of steel slags. As a matter of fact, recently our research group has reported the reduction of the slags produced in SIDERPERU plant [5] and 
also our initial achievements in recycling them into Q235 steel pieces [6], for which the information provided in the present work were very useful.

\section{Conclusions}

Remanent and demetallized slag produced in the ladle furnace from SIDERPERU steel plant were characterized by different techniques. The samples are hard sponge stones and dark grey in color. Fe, $\mathrm{Ca}, \mathrm{Si}$ and $\mathrm{Mn}$ are the main elements detected by both EDX and XRF analysis. The common iron oxide phases detected by XRD were magnetite and wustite. Larnite, ankerite manganese and hematite were also found in remanent slag. Kirschteinite, srebrodolskite and ankerite manganese are the mineralogical phases found in the demetallized slag. The magnetic measurements suggest the presence of a superparamagnetic phase screening the Verwey transition signal of magnetite and the Morin transition of hematite in both samples. The Mössbauer spectroscopy analysis reveals that magnetite and wustite are not in stoichiometric state and that the wustite contributes with paramagnetic doublets in the spectra. The remanent and demetallized slag produced in the ladle furnace in SIDERPERU steel plant are promising materials for recycling in the steelmaking industry due to their high iron content minerals.

Supplementary Information The online version contains supplementary material available at https:/doi. org/10.1007/s10751-022-01799-x.

Acknowledgements This work was supported by the CONCYTEC - World Bank - FONDECYT program "Incorporación de Investigadores", Contract No. 12 -2019 - FONDECYT - BM - INC. INV. The authors are indebted to Mr. E. Hurtado Aguilar and Mr. R.H Cervantes Altuna for allowing us access to SIDERPERU to collect the samples.

Open Access This article is licensed under a Creative Commons Attribution 4.0 International License, which permits use, sharing, adaptation, distribution and reproduction in any medium or format, as long as you give appropriate credit to the original author(s) and the source, provide a link to the Creative Commons licence, and indicate if changes were made. The images or other third party material in this article are included in the article's Creative Commons licence, unless indicated otherwise in a credit line to the material. If material is not included in the article's Creative Commons licence and your intended use is not permitted by statutory regulation or exceeds the permitted use, you will need to obtain permission directly from the copyright holder. To view a copy of this licence, visit http://creativecommons.org/licenses/by/4.0/.

\section{References}

1. Gomes, H.I., Funari, V., Mayes, W.M., Rogerson, M., Prior, T.J.: Recovery of Al, Cr and V from steel slag by bioleaching: Batch and column experiments. J. Environ. Manag. 222, 30-36 (2018). https://doi.org/10. 1016/j.jenvman.2018.05.056

2. Parron-Rubio, M.E., Perez-García, F., Gonzalez-Herrera, A., Rubio-Cintas, M.D.: Concrete properties comparison when substituting a $25 \%$ cement with slag from different provenances. Materials (Basel). 11, 1-13 (2018). https://doi.org/10.3390/ma11061029

3. Pellegrino, C., Faleschini, F.: Electric arc furnace slag concrete. Green Energy Technol. 0, 77-106 (2016). https://doi.org/10.1007/978-3-319-28540-5_4

4. Mombelli, D., Mapelli, C., Gruttadauria, A., Baldizzone, C., Magni, F., Levrangi, P.L., Simone, P.: Analisys of electric arc furnace slag. Steel Res. Int. 83, 1012-1019 (2012). https://doi.org/10.1002/srin.201100259

5. Espinoza Suarez, S.M., Borja-Castro, L.E., Valerio-Cuadros, M., Bustamane Domínguez, A., CabreraTinoco, H.A., Huaman, E., Valencia-Bedregal, R.A., Zhao, X., Zhang, Y., Zhang, D., Barnes, C.H.W., Valladares, D.L.S., L.: Carbothermal reduction of mill scales formed on steel billets during continuos casting. Hyperfine Interact. 242, 29 (2021). https://doi.org/10.1007/s10751-021-01769-9 
6. Villasante Miranda, A.G., Borja Castro, L.E., Valencia-Bedregal, R.A., Espinoza Suarez, S.M., ValerioCuadros, M.I., Bustamante Domínguez, A., Zhao, X., Zhang, Y., Zheng, C., Barnes, C.H.W., Zhang, D., De Los Santos Valladares, L.: Characterization of recycled Q235 steel chips from rolling billet scales. Hyperfine Interact. 242, 34 (2021). https://doi.org/10.1007/s10751-021-01764-0

7. Wang, G.C.: Ferrous metal production and ferrous slags. Util. Slag Civ. Infrastruct. Constr. 9-33 (2016). https://doi.org/10.1016/b978-0-08-100381-7.00002-1

8. Yildirim, I.Z., Prezzi, M.: Chemical, mineralogical, and morphological properties of steel slag. Adv. Civ. Eng. 2011, (2011). https://doi.org/10.1155/2011/463638

9. Yi, H., Xu, G., Cheng, H., Wang, J., Wan, Y., Chen, H.: An Overview of Utilization of Steel Slag. Procedia Environ. Sci. 16, 791-801 (2012). https://doi.org/10.1016/j.proenv.2012.10.108

10. Setién, J., Hernández, D., González, J.J.: Characterization of ladle furnace basic slag for use as a construction material. Constr. Build. Mater. 23, 1788-1794 (2009). https://doi.org/10.1016/j.conbuildmat.2008.10. 003

11. Sáez-De-Guinoa Vilaplana, A., Ferreira, V.J., López-Sabirón, A.M., Aranda-Usón, A., Lausín-González, C., Berganza-Conde, C., Ferreira, G.: Utilization of Ladle Furnace slag from a steelwork for laboratory scale production of Portland cement. Constr. Build. Mater. 94, 837-843 (2015). https://doi.org/10.1016/j. conbuildmat.2015.07.075

12. Manso, J.M., Ortega-López, V., Polanco, J.A., Setién, J.: The use of ladle furnace slag in soil stabilization. Constr. Build. Mater. 40, 126-134 (2013). https://doi.org/10.1016/j.conbuildmat.2012.09.079

13. Skaf, M., Ortega-López, V., Fuente-Alonso, J.A., Santamaría, A., Manso, J.M.: Ladle furnace slag in asphalt mixes. Constr. Build. Mater. 122, 488-495 (2016). https://doi.org/10.1016/j.conbuildmat.2016.06. 085

14. Hechavarría, R., López, G.: Fundamentals of Steelmaking by E. T. Turkdogan. J. Chem. Inf. Model. 53, 1689-1699 (2013). https://doi.org/10.1017/CBO9781107415324.004

15. Menad, N.E., Kana, N., Seron, A., Kanari, N.: New eaf slag characterization methodology for strategic metal recovery. Materials (Basel). 14, (2021). https://doi.org/10.3390/ma14061513

16. Ter Teo, P., Zakaria, S.K., Salleh, S.Z., Taib, M.A.A., Sharif, N.M., Seman, A.A., Mohamed, J.J., Yusoff, M., Yusoff, A.H., Mohamad, M., Masri, M.N., Mamat, S.: Assessment of electric arc furnace (EAF) steel slag waste's recycling options into value added green products: A review. Metals (Basel). 10, 1-21 (2020). https://doi.org/10.3390/met10101347

17. Chen, C.J., Chiang, R.K., Lai, H.Y., Lin, C.R.: Characterization of monodisperse wüstite nanoparticles following partial oxidation. J. Phys. Chem. C. 114, 4258-4263 (2010). https://doi.org/10.1021/jp908153y

18. Estrader, M., López-Ortega, A., Golosovsky, I.V., Estradé, S., Roca, A.G., Salazar-Alvarez, G., LópezConesa, L., Tobia, D., Winkler, E., Ardisson, J.D., Macedo, W.A.A., Morphis, A., Vasilakaki, M., Trohidou, K.N., Gukasov, A., Mirebeau, I., Makarova, O.L., Zysler, R.D., Peiró, F., et al.: Origin of the large dispersion of magnetic properties in nanostructured oxides: FexO/Fe3O4 nanoparticles as a case study. Nanoscale. 7, 3002-3015 (2015). https://doi.org/10.1039/c4nr06351a

19. Guntlin, C.P., Ochsenbein, S.T., Wörle, M., Erni, R., Kravchyk, K.V., Kovalenko, M.V.: Popcorn-Shaped FexO (Wüstite) Nanoparticles from a Single-Source Precursor: Colloidal Synthesis and Magnetic Properties. Chem. Mater. 30, 1249-1256 (2018). https://doi.org/10.1021/acs.chemmater.7b04382

20. García, J., Subías, G.: The Verwey transition - A new perspective. J. Phys. Condens. Matter. 16, (2004). https://doi.org/10.1088/0953-8984/16/7/R01

21. Özdemir, Ö., Dunlop, D.J., Berquó, T.S.: Morin transition in hematite: Size dependence and thermal hysteresis. Geochemistry, Geophys. Geosystems. 9, (2008). https://doi.org/10.1029/2008GC002110

22. Benard, J.: The oxidation of metals and alloys. Metall. Rev. 9, 473-503 (1964). https://doi.org/10.1179/ mtlr.1964.9.1.473

23. Gheisari, M., Mozafari, M., Niyaifar, M., Amighian, J., Soleimani, R.: Observation of small exchange bias in defect wüstite (Fe 0.93O) nanoparticles. J. Supercond. Nov. Magn. 26, 237-242 (2013). https://doi.org/ 10.1007/s10948-012-1821-9

24. Doriguetto, A.C., Fernandes, N.G., Persiano, A.I.C., Nunes Filho, E., Grenèche, J.M., Fabris, J.D.: Characterization of a natural magnetite. Phys. Chem. Miner. 30, 249-255 (2003). https://doi.org/10.1007/ s00269-003-0310-X

25. Gütlich, P., Eckhard, B., Operario, D., Trautwein X.A,: Mössbauer Spectroscopy and Transition Metal Chemistry. Springer (2017)

26. Dyar, M.D., Agresti, D.G., Schaefer, M.W., Grant, C.A., Sklute, E.C.: Mössbauer spectroscopy of Earth and planetary materials. Annu. Rev. Earth Planet. Sci. 34, 83-125 (2006). https://doi.org/10.1146/annurev. earth.34.031405.125049

27. Vandenberghe, R.E., Barrero, C.A., Da Costa, G.M., Van San, E., De Grave, E.: Mössbauer characterization of iron oxides and (oxy)hydroxides: The present state of the art. Hyperfine Interact. 126, 247-259 (2000). https://doi.org/10.1023/A:1012603603203 
28. Liu, M., Li, H., Xiao, L., Yu, W., Lu, Y., Zhao, Z.: XRD and Mössbauer spectroscopy investigation of Fe2O 3-Al2O3 nano-composite. J. Magn. Magn. Mater. 294, 294-297 (2005). https://doi.org/10.1016/j. jmmm.2004.12.026

29. Nininger Jr., R.C., Schroeer, D.: Mossauer Studies of the Morin Transition in Bulk and Microcrystalline alpha-Fe2O3. J. Phys. Chem. Solids. 39, 137-144 (1978)

30. Grenier, J.C., Menil, F., Pouchard, M., Hagenmuller, P.: Mössbauer resonance studies in the CaTiO3Ca2Fe2O5 system. Mater. Res. Bull. 13, 329-337 (1978). https://doi.org/10.1016/0025-5408(78)90011-9

31. Gunstone, F.D.: Mössbauer Mineral Handbook. (2011)

Publisher's note Springer Nature remains neutral with regard to jurisdictional claims in published maps and institutional affiliations.

\section{Authors and Affiliations}

A. G. Bustamante Dominguez ${ }^{1}$ - M. I. Valerio-Cuadros ${ }^{1,2}$.

L. E. Borja-Castro ${ }^{1} \cdot$ R. A. Valencia-Bedregal ${ }^{1} \cdot$ J. Flores Santibañez ${ }^{1}$.

S. M. Espinoza Suarez ${ }^{1}$. H. Cabrera-Tinoco ${ }^{1,3} \cdot$ N.O Moreno ${ }^{4} \cdot$ C. H. W. Barnes ${ }^{5}$.

L. De Los Santos Valladares ${ }^{1,5,6}$ (D)

1 Laboratorio de Cerámicos y Nanomateriales, Facultad de Ciencias Física, Universidad Nacional Mayor de San Marcos, Ap. Postal 14-0149, Lima, Peru

2 Departamento de Física, Universidade Estadual de Maringá, Av. Colombo, 5790 - Jardim Universitário, Maringá, PR 87020-900, Brazil

3 Facultad de Ingeniería, Universidad Continental, 15311 Lima, Peru

4 Departamento de Física, Universidade Federal de Sergipe, São Cristóvão, SE 49100-000, Brazil

5 Cavendish Laboratory, Department of Physics, University of Cambridge, J.J Thomson Av, Cambridge CB3 OHE, UK

6 School of Materials Science and Engineering, Northeastern University, No 11, Lane 3, Wenhua Road, Heping District, Shenyang 110819, Liaoning, People's Republic of China 